Journal of Southeast Asian

\title{
Two Poems: Vertigo; lockdown
}

Jer Xiong

jxiong21@mail.fresnostate.edu

Follow this and additional works at: https://docs.lib.purdue.edu/jsaaea

Part of the Bilingual, Multilingual, and Multicultural Education Commons

\section{Recommended Citation}

Xiong, Jer (2021) "Two Poems: Vertigo; lockdown," Journal of Southeast Asian American Education and Advancement: Vol. 16 : Iss. 1, Article 6.

DOI: $10.7771 / 2153-8999.1228$

Available at: https://docs.lib.purdue.edu/jsaaea/vol16/iss1/6

This document has been made available through Purdue e-Pubs, a service of the Purdue University Libraries. Please contact epubs@purdue.edu for additional information.

This is an Open Access journal. This means that it uses a funding model that does not charge readers or their institutions for access. Readers may freely read, download, copy, distribute, print, search, or link to the full texts of articles. This journal is covered under the CC BY-NC-ND license. 


\section{ISAAEA Journal of Southeast Asian American Education and Advancement}

Vol. 16 Iss. 1 (2021)

WWW.JSAAEA.org

\section{Creative and Literary Works}

\section{Two Poems}

\section{Jer Xiong}

\section{Vertigo}

The mountains do not direct propriety, no, neither do the winds lead to my proper name. I pen what's found at isle's enduntitled coordinates, unbecoming tidesand mother foretells me as the bad left destined to break

$$
\text { off. }
$$

My path is fraught.

This burden one writes new rites. When stars reveal only crumbling compasses,

I must plot a light from the axis

beyond.

Where you go, mother chides, I will not know.

Between us, the point of return remains uncharted.

\footnotetext{
(c)

SDRERIIGHISRESERNEDReaders are free to copy, display, and distribute this article, as long as the work is attributed to the author(s) and the Journal of Southeast Asian American Education \& Advancement, it is distributed for non-commercial purposes only, and no alteration or transformation is made in the work. More details of this Creative Commons license are available at http://creativecommons.org/licenses/by-nc-nd/3.0/. All other uses must be approved by the author(s) or JSAAEA. Journal of Southeast Asian American Education \& Advancement, Vol. 16. Iss. 1. (2021) ISSN: 2153-8999
} 


\section{lockdown}

I only wish to return but the living lies inside the bones of home. I sweep dusty corners to drive out phantoms. Binding prayers on doorways draws no relief in inventory-far from you, separated by virus, highways, and the seconds are less forgiving than last year - the patio cactus is drowned. I thought I knew how to keep alive.

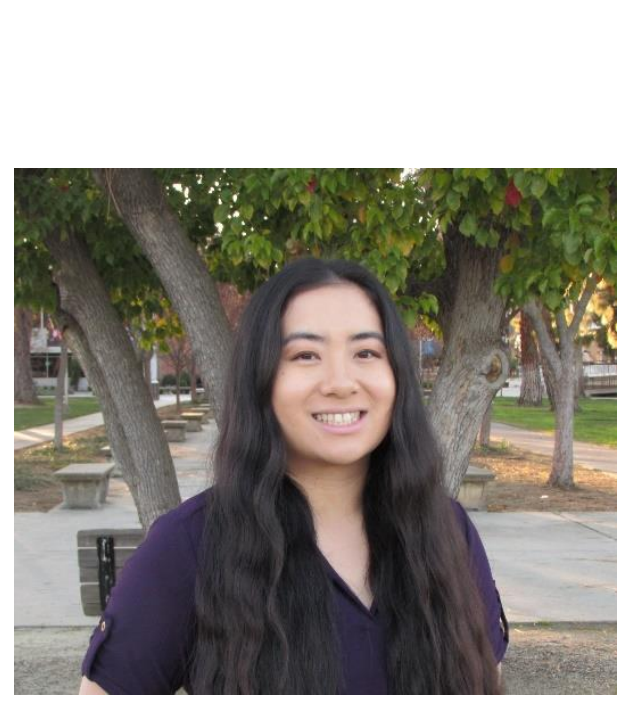

\section{About the Author}

Jer Xiong is a Hmong American writer and a Nonfiction candidate in the MFA Creative Writing program at California State University, Fresno. She's been an editor for the Watershed Review and The Normal School. Her works have appeared in maivmai; (559) JOU-RNAL; Celebrate Hmong; Flies, Cockroaches, and Poets; and Pos Moua's Karst Mountains Will Bloom. She's a member of the Hmong American Writers' Circle (HAWC) and cofounder of Hmong American Ink \& Stories (HAIS). 


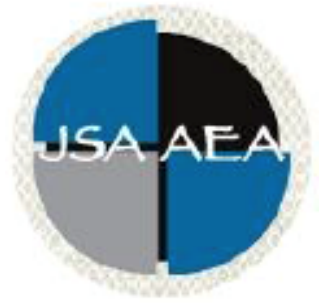

Vol.16 Iss.1 (2021)

\title{
Journal of Southeast Asian American Education and Advancement
}

\author{
WWW.JSAAEA.org
}

\section{Editor}

Dr. Wayne E. Wright

Purdue University

Associate Editors

Dr. Chhany Sak-Humphry

University of Hawaii at Manoa

Dr. Phitsamay Sychitkokhong Uy

University of Massachusetts, Lowell

\author{
Book Review Editor \\ Dr. Vichet Chhuon \\ University of Minnesota \\ Creative Works Editor \\ Bryan Thao Worra \\ Lao Assistance Center \\ Journal Manager \\ Chen Li \\ Jeffrey Sovan Wright \\ Purdue University
}

\section{Editorial Review Board}

\author{
Dr. Steve Arounsack \\ California State University, Stanislaus \\ Dr. Sovicheth Boun \\ Salem State University \\ Dr. Virak Chan \\ Purdue University \\ Dr. Loan Dao \\ University of Massachusetts Boston
}

\author{
Dr. Carl L. Bankston III \\ Tulane University \\ Dr. Phala Chea \\ Lowell Public Schools \\ Dr. George Chigas \\ University of Massachusetts, Lowell \\ Dr. Hien Duc Do \\ San Jose State University
}




\author{
Dr. Linh Dang \\ KIPP DC Headquarters \\ Dr. Sophal Ear \\ Occidental College \\ Dr. Vincent K. Her \\ University of Wisconsin, Eau Claire \\ Dr. Nancy H. Hornberger \\ University of Pennsylvania \\ Dr. Peter Tan Keo \\ New York University \\ Dr. Yvonne Kwan \\ San Jose State University \\ Dr. Ravy Lao \\ California State University, Los Angeles \\ Dr. Stacey Lee \\ University of Wisconsin, Madison \\ Dr. Jacqueline Mac \\ Northern Illinois University \\ Dr. Bic Ngo \\ University of Minnesota \\ Dr. Leakhena Nou \\ California State University, Long Beach \\ Dr. Mark Pfeifer \\ SUNY Institute of Technology \\ Dr. Loan T. Phan \\ University of New Hampshire \\ Dr. Karen Quintiliani \\ California State University, Long Beach \\ Dr. Angela Reyes \\ Hunter College \\ The City University of New York \\ Dr. Fay Shin \\ California State University, Long Beach \\ Dr. Christine Su \\ College of San Mateo \\ Dr. Alisia Tran \\ Arizona State University \\ Dr. Khatharya Um \\ University of California, Berkeley \\ Dr. Kim Tran \\ University of California, Los Angeles, \\ Glendale Community College \\ Dr. Molly Wiebe \\ The University of Texas at Austin \\ Dr. Changming Duan \\ University of Missouri-Kansas City \\ Dr. Sothy Eng \\ Lehigh University \\ Dr. Jeremy Hein \\ University of Wisconsin, Eau Claire \\ Dr. Peter Nien-Chu Kiang \\ University of Massachusetts, Boston \\ Dr. Kevin K. Kumashiro \\ University of Illinois, Chicago \\ Dr. Ha Lam \\ Independent Scholar \\ Dr. Jonathan H. X. Lee \\ San Francisco State University \\ Dr. Monirith Ly \\ Royal University of Phnom Penh \\ Dr. Sue Needham \\ California State University, Dominguez Hills \\ Dr. Max Niedzwiecki \\ Daylight Consulting Group \\ Dr. Clara Park \\ California State University, Northridge \\ Dr. Giang Pham \\ University of Massachusetts Amherst \\ Dr. Malaphone Phommasa \\ University of California Santa Barbara \\ Dr. Kalyani Rai \\ University of Wisconsin-Milwaukee \\ Dr. Cathy J. Schlund-Vials \\ University of Connecticut, Storrs \\ Dr. Nancy J. Smith-Hefner \\ Boston University \\ Dr. Yer J. Thao \\ Portland State University \\ Dr. Monica M. Trieu \\ Purdue University \\ Dr. Silvy Un \\ Saint Paul Public Schools \\ Dr. Linda Trinh Vo \\ University of California, Irvine \\ Dr. Varaxy Yi Borromeo \\ California State University, Fresno \\ Dr. Yang Sao Xiong \\ The University of Wisconsin-Madison

\section{Dr. Zha Blong Xiong} \\ University of Minnesota
}




\section{Doctoral Student Editorial Review Board}

Diana Chandara
University of Minnesota-Twin Cities
Bao Diep
University of Minnesota-Twin Cities
Vanessa Sovanika Na
University of California San Diego
Khoi Nguyen
George Mason University
Hoa Nha Nguyen
Boston College
Linda Marie Pheng
University of Wisconsin-Madison
Latana Thaviseth
University of California Los Angeles
Melissa Vang
San Diego State University

\author{
Kassandra Chhay \\ University of Minnesota-Twin Cities \\ Annie BichLoan Duong \\ San Joaquin County Office of Education \\ Nielson Hul \\ Cornell University \\ Dung Minh Mao \\ University of Minnesota-Twin Cities \\ Thien-Huong Ninh \\ University of Southern California \\ Krissyvan Truong \\ Claremont Graduate University \\ Mai Vang \\ University of Massachusetts Boston \\ Thong Vang \\ University of Minnesota-Twin Cities
}

Soua Xiong

San Diego State University

Claremont Graduate University 